\title{
EUCARISTIA E DIALOGISMO NA SACRAMENTUM CARITATIS
}

\author{
EUCHARIST AND DIALOGISM IN SACRAMENTUM CARITATIS
}

\author{
NANCI MOREIRA BRANCO(*) \\ JosÉ REINALDO F. MARTINS FILHO ${ }^{(* *)}$
}

\begin{abstract}
RESUMO
Ao longo de nossa pesquisa temos realçado as diferentes maneiras de nos aproximarmos do discurso religioso, sobretudo em vista do que entendemos por seu caráter ideológico e repleto de dialogismos. Neste trabalho, partiremos do que é desenvolvido por Bakhtin e seu círculo ao tratarem o discurso como uma construção dinâmica e responsiva. Em suma, trata-se de analisar a relação entre Eucaristia e dialogismo, tomando como objeto a exortação apostólica Sacramentum Caritatis, do atual papa emérito Bento XVI. Entre outros, serão demonstrados elementos tais como, o aspecto alegórico da Eucaristia como rito, cujo significado vai muito além do nível meramente conceitual. Além disso, também serão realçadas algumas questões polêmicas e sua relação com o dialogismo ao longo do documento, entre elas: a Eucaristia e a questão da verdade no cristianismo, a Eucaristia e a indissolubilidade do matrimônio, a Eucaristia e a defesa da vida humana e o sentido do repouso e do trabalho. Em suma, pretendemos contribuir no fortalecimento das discussões e da compreensão em torno do tema proposto, bem como dos demais interesses que lhe são correlatos, num entrelaçamento de vozes as quais esta pesquisa também deseja suscitar.
\end{abstract}

PALAVRAS-ChaVE: Dialogismo. Eucaristia. Bakhtin. Sacramentum Caritatis.

\section{ABSTRACT}

Over the course of our research we have highlighted the different ways to approach the religious discourse, especially in view of what we mean by ideological and full of character dialogismos. In this work we leave than is developed by Bakhtin and his circle to treat the speech as a dynamic and responsive construction. In short, it is to analyze the relationship between the Eucharist and dialogism taking as objectSacramentum Caritatis the Apostolic Exhortation, the current Pope Emeritus Benedict XVI. Among others, elements will be demonstrated such as the allegorical aspect of the Eucharist as a rite whose meaning goes beyond the merely conceptual level. Also, they will also be highlighted some controversial issues and their relationship to dialogism throughout the document, including: the Eucharist and the question of truth in Christianity, the Eucharist and the indissolubility of marriage, the Eucharist and the defense of human life and sense of home and work. In short, we aim to contribute to the strengthening of discussions and understanding around the proposed theme as well as other interests that are related in an interweaving of voices which this research would also like to raise.

KEYWORDS: Dialogism. Eucharist. Bakhtin. Sacramentum Caritatis

${ }^{(*)}$ Mestra e doutoranda em Linguística pela UFSCar (Universidade Federal de São Carlos). Professora de Educação Básica da Rede Oficial de Ensino do Estado de São Paulo. Email: nancimbranco@ig.com.br

${ }^{(* *)}$ Mestre em Filosofia pela UFG. Mestrando em Música pela UFG. Graduado em Filosofia e Teologia. Professor no Instituto de Filosofia e Teologia de Goias (IFITEG).

E-mail: jreinaldomartins@gmail.com 
A Eucaristia é o memorial perene de sua Paixão, o cumprimento perfeito das figuras da Antiga Aliança e o maior de todos os milagres que Cristo realizou.

(Santo Tomás de Aquino, Opusculum 57)

Este artigo tem como objetivo analisar como se dão as relações dialógicas na exortação apostólica Sacramentum Caritatis. Para tanto, recorremos a conceitos desenvolvidos nos estudos do filósofo russo Mikhail Bakhtin e de seu Círculo, especialmente: dialogismo e ideologia.

A princípio, gostaríamos de expor um breve entendimento acerca de tais conceitos, que são fundamentais nos trabalhos e no pensamento de Bakhtin e do seu Círculo․ Partindo do estudo do enunciado ${ }^{2}$, podemos entender o dialogismo a partir da ideia de que todo enunciado é dialógico, ou seja,

todo enunciado constitui-se a partir de outro enunciado, é uma réplica a outro enunciado. Portanto, nele ouvem-se sempre, ao menos, duas vozes. Mesmo que elas não se manifestem no fio do discurso, estão aí presentes. Um enunciado é sempre heterogêneo, pois ele revela duas posições, a sua e aquela em oposição à qual ele se constrói. Ele exibe seu direito e seu avesso. (FIORIN, 2008, p.24)

Os estudos de Bakhtin e de seu Círculo mostram, ainda, que todo enunciado é ideológico, pois expressa sempre uma posição social valorativa. Assim, "qualquer enunciado se dá na esfera de uma das ideologias (i.e., no interior de uma das áreas da atividade intelectual humana) e expressa sempre uma posição avaliativa (i.e., não há enunciado neutro; a própria retórica da neutralidade é também uma posição axiológica)" (Faraco, 2009, p. 47). Os estudos do Círculo, também, destacam que ao lado da ideologia oficial, encontramos uma ideologia do cotidiano.

A ideologia oficial é entendida como relativamente dominante, procurando implantar uma concepção única de produção de mundo. A ideologia do cotidiano é considerada como a que brota e é construída nos encontros casuais e fortuitos, no lugar do nascedouro dos sistemas de referência, na proximidade social com as condições de produção e reprodução da vida (MIOTELLO, 2008, p.168-169).

\footnotetext{
${ }^{1}$ No desenvolvimento da análise, retomaremos esses conceitos bem como outros, de acordo com o enfoque analítico.

2 Este é entendido como unidade real da comunicação discursiva, o que o diferencia das unidades da língua, como palavra e orações (Bakhtin, 2006a).
} 
Diante disso, entendemos que mesmo um discurso tão consolidado como o religioso sofre influências de vários outros com os quais partilha e aos quais contrapõe idéias ou delas faz uso para estabelecer o sentido do seu discurso. Dessa forma, o dialogismo, aqui, será observado no confronto que se dá entre o texto de Bento XVI (pautado na resolução dos bispos sinodais) e os discursos presentes na sociedade em diferentes contextos, referidos explícita e implicitamente pelo autor, ou, ainda, os discursos que se formam nos contextos diversos nos quais tais temas estão inseridos. Assim, a análise buscará compreender qual a relação que tal texto tem com os que circulam na sociedade. Entendemos, para tanto, que as relações dialógicas podem ser de convergência ou divergência, de aceitação ou recusa, pois os enunciados são o espaço de luta entre vozes sociais; logo, o lugar da contradição (FIORIN, 2008).

\section{EXORTAÇÃO APOSTÓLICA SACRAMENTUM CARITATIS}

Compreender o sentido simbólico que reveste todo e qualquer discurso, seja ele religioso ou não, requer, antes de tudo, descobrir o locus de sua gestação, o contexto a partir do qual ele se estabelece. No caso específico da Sacramentum Caritatis, torna-se salutar resgatar seu papel de conclusão do Sínodo3 dos Bispos, realizado pela Igreja Católica no ano de 2005, cujo tema central foi a dimensão eucarística da vida da Igreja. O costume de fazer Sínodos remete aos primórdios da Igreja. Enquanto os Concílios refletiam sobre questões dogmáticas referentes à Igreja universal, os Sínodos se concentravam nas problemáticas de cunho pastoral e prático, sempre diferentes em cada realidade específica.

No caso do Sínodo dos Bispos realizado em 2005, o tema escolhido como norte para as reflexões foi a Eucaristia. Desta feita, a finalidade da exortação

\footnotetext{
3 A palavra Sínodo encontra sua origem etimológica no grego antigo, na justaposição das

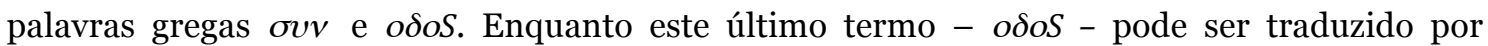
caminho, via, percurso (do mesmo modo como encontramos evidente na raiz da palavra método $[\mu \varepsilon \tau+o \delta o S]$, ou seja, um caminho), o prefixo $\sigma v v$ indica unidade, aquilo que reúne, que agrega ao redor de um mesmo pólo. Esse efeito pode ser visto em outros termos da língua portuguesa, tais como simbiose $(\sigma v v+\beta \iota o S=$ junção de vidas $)$ e símbolo $(\sigma v v+\beta o \lambda o v=$ jogar juntos $)$. Assim, Sínodo pode ser traduzido por: um caminho que se faz em conjunto, um caminho em unidade. As palavras de John Daiber ilustram o que tentamos dizer: "Uma caminhada [...] não é uma marcha em que todos andam em filas certinhas, no mesmo ritmo, na mesma cadência, batendo o pé no chão no mesmo instante. Numa caminhada, cada um anda com um passo diferente. Uma caminhada também não é uma corrida em que o importante é a velocidade. Uma caminhada pode durar dias e, tratando-se de um sínodo, vários anos. Quando você participa de uma caminhada, você tem a oportunidade de conversar com muita gente, porque nem todos caminham no mesmo ritmo. [...] Assim, cada um terá melhores condições de opinar sobre aquilo que diz respeito a todos" (Daiber apud Cruz, 2008, p. 11-12).
} 
apostólica Sacramentum Caritatis é dupla: por um lado, explicitar algumas linhas fundamentais de ação orientadas a suscitar na Igreja um novo impulso e um novo fervor para com a Eucaristia e, de outro, fazer com que o povo cristão se aprofunde, sempre mais, na relação entre o mistério eucarístico, o ato litúrgico e o novo culto espiritual que derivam da Eucaristia como sacramento de caridade ( Sacramentum Caritatis, adiante SC, n.54).

Poderíamos nos perguntar: qual a importância de uma compreensão teológica - até mesmo eclesiológica - do evento Sínodo dos Bispos para uma análise linguística e filosófica do documento que se constitui como sua súmula? Em primeiro lugar, é notório o apelo para a dimensão co-participativa desse discurso. Ao contrário de outras encíclicas papais, escritas nos moldes de alocuções aos bispos do mundo inteiro, exortações apostólicas com finalidade pedagógica, simbólica ou, até mesmo, cultural, através das quais é reafirmado o sentido de unidade expresso pela figura do Sumo Pontífice, a súmula de um Sínodo representa a conciliação de diferentes ideologias, muitas delas divergentes entre si; o extrato de realidades distintas, de uma multiplicidade de matizes culturais, do oriente ao ocidente. $\mathrm{O}$ discurso nela gestado torna-se a expressão de uma polifonia de sujeitos alienados em função de uma pretendida unidade; sujeitos que abdicam de suas vozes individuais em função da voz do todo, o que não significa, entretanto, que essas vozes sejam apagadas no discurso. Isso em muito se difere da crise de identidade imposta à vida cotidiana, uma impessoalidade na qual todas as partes se encontram, embora nenhuma delas ali se reconheça. A ausência de rostos, no discurso que analisamos, é fruto da construção de uma identidade própria, uma universalidade que nasce das partes, dos particulares, e avança, num crescendum contínuum ad universalis. Não há aqui a extinção das partes, mas sua integração no universal. É a "voz da Igreja” que, embora se pretenda única, carrega em si toda a diversidade construída nos diferentes contextos em que está inserida.

Martínez Lorenzo, em sua análise sobre a Sacramentum Caritatis, recorda que a divisão tripartida (crer, celebrar e viver), que constitui o corpo da exortação, se situa entre dois pontos fulcrais para a fé cristã. $O$ primeiro recorda a origem da Eucaristia como sacramento de caridade. A Eucaristia é interpretada como dom: dom que Jesus Cristo faz de si mesmo em prol dos outros. Aqui se manifesta o "maior amor", aquele que impulsiona a "dar a vida pelos próprios amigos" (Jo 15,13). No sacramento eucarístico, o Senhor segue amando ao extremo, até o dom

\footnotetext{
4 As referências da exortação apostólica Sacramentum Caritatis são dadas pelo número do parágrafo.
} 
de seu Corpo e seu Sangue (cf. SC n.1). A segunda luz à qual Lorenzo se refere se projeta a partir da conclusão, aludindo aos efeitos da Eucaristia. Ali lemos:

A Eucaristia é a origem de toda forma de santidade, sendo cada um de nós chamado à plenitude de vida no Espírito Santo. Quantos santos tornaram autêntica a própria vida, graças à sua piedade eucarística! De santo Inácio de Antioquia a santo Agostinho, de santo Antão Abade a são Bento, de são Francisco de Assis a são Tomás de Aquino, de santa Clara de Assis a santa Catarina de Sena, de são Pascoal Bailão a são Pedro Julião Eymard, de santo Afonso Maria de Ligório ao beato Carlos de Foucauld, de são João Maria Vianey a santa Teresa de Lisieux, de são Pio de Pietrelcina à beata Teresa de Calcutá, do beato Pedro Jorge Frassati ao beato IvanMertz, para mencionar apenas alguns de tantos nomes, a santidade sempre encontrou o seu centro no sacramento da Eucaristia (SC n.94).

De certa maneira, aqui encontramos referência ao que João Paulo II denominava por "mistério de luz"5. Não somente isso. O diálogo com a Tradição pode ser percebido pelas constantes referências à história da Igreja, sobretudo à vida dos santos, ao seu testemunho eucarístico. Quanto ao conteúdo da exortação, entre os extremos, introdução e conclusão, se desenvolvem as três partes que a compõem. O mistério eucarístico é abordado pela perspectiva da fé, da celebração e da vida cristã. Para as três partes, o embasamento teológico adota como fonte de inspiração o capítulo 6 do evangelho de João: o discurso sobre o Pão da Vida. Na primeira parte, a Eucaristia é tomada como mistério da fé, conteúdo para ser crido: “a obra de Deus é que acrediteis naquele que ele enviou" (Jo 6,29). Entretanto, a atitude da fé conduz à celebração da vida e, portanto, à Eucaristia como mistério para ser celebrado. Isso constitui a segunda parte da exortação: "não foi Moisés quem vos deu o pão do céu. É meu Pai quem vos dá o verdadeiro pão do céu” (Jo 6,32). Enfim, o ciclo iniciado no movimento da razão rumo à crença, que passa pela celebração, conduz à apropriação da Eucaristia como mistério para se viver: "como o Pai, que vive, me enviou, e eu vivo por meio do Pai, assim aquele que de mim se alimenta viverá por meio de mim" (Jo 6, 57).

Segundo o Magistério da Igreja Católica, “a Eucaristia6 é um sacrifício de ação de graças ao Pai, uma bênção pela qual a Igreja exprime seu reconhecimento a

5 Ver João Paulo II, Carta Apostólica Mane Nobiscum Domine, n. 11ss.

${ }^{6}$ Sobre a origem etimológica e a amplitude semântica do signo Eucaristia no meio cristão católico, podemos fazer algumas considerações. A expressão latina Eucharistia remonta ao substantivo grego $\kappa \alpha \rho \iota s$, traduzido por "favor", "graça", "auxílio", dentre outros. Uma de suas mais comuns declinações é a fórmula $\kappa \alpha \rho \iota \zeta \varepsilon \sigma \theta \alpha \iota$, que significa "mostrar favor ou agrado por". Com a adição do prefixo $\varepsilon v$ (bem), obtemos a construção $\varepsilon v \kappa \alpha \rho \iota \sigma \tau o s$, ou seja, [estar] "agradecido". Desse modo, em sua origem grega, o signo Eucaristia ( $\varepsilon v \kappa \alpha \rho \iota \sigma \theta \iota \alpha)$ carrega o sentido de "gratidão, agradecimento". Os primeiros cristãos adotaram essa expressão para 
Deus por todos os seus benefícios, por tudo o que ele realizou por meio da criação, da redenção e da santificação" (CIC, n.1360). Mais que isso, o valor desse sublime sacramento, ou, nos termos de Tomás de Aquino, desse sacramento dos sacramentos, se estende por toda a dinâmica eclesial. No parágrafo 47 da Sacrosanctum Concilium, encontramos o substrato do que a Eucaristia representa para o cristianismo católico:

na última ceia, na noite em que foi entregue, nosso Salvador instituiu o Sacrifício Eucarístico de seu Corpo e Sangue. Por ele, perpetua pelos séculos, até que volte, o sacrifício da cruz, confiando destarte à Igreja, sua dileta esposa, o memorial de sua morte e ressurreição: sacramento da piedade, sinal da unidade, vínculo da caridade, banquete pascal em que Cristo é recebido como alimento, o espírito é cumulado de graça e nos é dado o penhor da glória futura.

Note-se, sobremaneira, o valor escatológico da Eucaristia enquanto antecipação da vida eterna. Além disso, a questão da presença real de Cristo na Eucaristia - um dos objetos de discussão do Concílio de Trento - permanece como centralidade de todos os sentidos: "no santíssimo sacramento da Eucaristia estão contidos verdadeiramente, realmente e substancialmente o Corpo e o Sangue juntamente com a alma e a divindade de Nosso Senhor Jesus Cristo e, por conseguinte, o Cristo todo" (DENZINGER, Con. de Trento: DS, 1651).

\subsection{SOBRE A EUCARISTIA COMO RITO}

No que se refere ao caráter ritual da Eucaristia como Mistério Celebrado, o Sínodo dos bispos também enfatizou diversos aspectos que merecem nossa atenção. Na Eucaristia, por exemplo, encontra-se expressa a unidade mística da Igreja, muitos membros constituídos ao redor de Cristo cabeça. Por isso o termo "comunhão" é frequentemente utilizado para designar o momento específico do banquete eucarístico. Não se limitando a uma esmiuçada explicitação da estrutura da missa, Sacramentum Caritatis nos adverte sobre importantes pontos da relação

designar a celebração que realizavam na manhã do primeiro dia da semana: a Ação de Graças por excelência, a reunião dos batizados ao redor da mesa, a partilha do pão, a ceia, noutras palavras, a memória da Páscoa cristã (Paixão, Morte e Ressurreição de Cristo). Não apenas isso: o valor dessa celebração se estendia aos que estavam impossibilitados da participação física, os doentes e encarcerados, por exemplo. A relação entre Eucaristia e Caridade, portanto, está tanto na origem do próprio signo - que designa agradecimento pelo benefício recebido - quanto no modus operandi da celebração. Data-se daí a acepção da Eucaristia como fonte e cume da vida eclesial expressa pela constituição Sacrosanctum Concilium (n.10) do Concílio Vaticano II e frequentemente retomada por Bento XVI, em seu múnus ensinando: "a Eucaristia é o coração e o ápice da vida da Igreja, pois nela Cristo associa sua Igreja e todos os seus membros a seu sacrifício de louvor e de ação de graças oferecido uma vez por todas na cruz a seu Pai" (CIC, n. 1407). 
entre Mistério Celebrado e Mistério Crido. Como exemplo, vale a pena notarmos o subtítulo que se refere à "ativa participação dos fiéis". Trata-se de tomar consciência da multiplicidade de ministérios que colaboram no culto eucarístico. A igual condição de todos torna-se o passo necessário para a celebração da fé: "não há judeus, nem gregos, nem escravos, nem livres, nem homens, nem mulheres, porque todos sois um só em Cristo" (Gl 3, 27-28). A relação entre Eucaristia e Caridade, delineada desde o título do documento, vê-se novamente enfatizada no aspecto celebrativo. Entender a Eucaristia como o sacramento do amor/caridade significa atribuir à caridade o papel de baluarte do cristianismo - ponto fulcral do testemunho cristão: "acima de tudo a caridade, que é o vínculo da perfeição (Cl $3,14)$.

O apelo à inculturação, importante ponto a ser explorado na relação entre a liturgia e a vida - por ora mais tímido que há algumas décadas, no calor do Concílio Vaticano II - encontra ressonância no parágrafo 54 deste documento. Trata-se, certamente, de um dos maiores apelos litúrgicos de nossa época. Celebrar o mistério da Eucaristia requer uma total configuração com a realidade social e cultural em que se está inserido. Requer, simultaneamente, zelo pela tradição/doutrina e sensibilidade para com os clamores dos tempos. De outro modo, não é possível reviver os mesmos sentimentos e possuir o mesmo coração do Cristo que parte o pão e o reparte entre todos. A esse respeito, notamos certo paradoxo: como conciliar esse apelo por inculturação com o incentivo de retomada da língua latina como cotidiana possibilidade de expressão do Mistério Celebrado? Este, de fato, foi um dos pontos mais explorados pelos meios de comunicação quando da publicação de Sacramentum Caritatis. O tom inicial do parágrafo 62, que trata do uso do latim na Eucaristia, enunciado em primeira pessoa do singular revela a perspectiva de um sujeito individual: "o que acabo de afirmar não deve, porém, ofuscar o valor dessas grandes liturgias. [...] Quero recomendar o que foi sugerido pelo Sínodo dos Bispos [...]: excetuando as leituras, a homilia e a oração dos fiéis, é bom que tais celebrações sejam em língua latina” (SC, n. 62). O texto continua propondo o uso do canto gregoriano, sempre que possível, bem como a retomada dos cursos de latim nos seminários, a fim de que os novos presbíteros possuam domínio sobre essa língua. A ressonância a essa proposta não adveio apenas dos meios laicos de comunicação. Mesmo no seio da Igreja, as reações não foram as mais cordiais. Para muitos, "ressuscitar" o latim como língua da missa significa retomar a perspectiva teológica e eclesiológica tridentina, regida pelo modelo piramidal e, em certa medida, excludente de participação nas celebrações. “Celebrar” é um termo difundido, sobretudo, após o movimento em prol da 
reforma litúrgica, iniciado no final do século XVIII. Antes disso, a Eucaristia era “dita”, não “celebrada”. Para além da dimensão do Sacrifício, o uso do vernáculo, a partir do Concílio Vaticano II, reforçou, em muito, a concepção da Eucaristia como Banquete, as Núpcias do Cordeiro. A aparente "regressão" de concepções coopera na manutenção de uma imagem conservadora e anacrônica da Igreja, representada por Bento XVI.

Essa questão gerou alguns discursos que responderam às palavras de Bento XVI e às propostas dos padres sinodais:

A encíclica apoia a missa em latim e de costas para o povo, ao lado da missa nas línguas modernas e de frente para o povo. Aqui se revelam dois modelos de Igreja: um jurídico e autoritário, em latim e de costas para o povo. O outro, pastoral e participativo, nas línguas modernas e de frente para o povo. Os que querem o latim é por razões estéticas e tradicionais e não por razões de comunicação com o povo. O latim seria apenas para as elites que até entendem algo. Para a grande maioria, a missa deve ser compreendida, portanto, celebrada nas línguas vernáculas ${ }^{7}$.

Outros elementos, ainda, merecem destaque. Num tempo em que o discurso ecumênico parece fracassar, confinando à lembrança o impulso de um Concílio que acaba de completar cinco décadas de história, a participação dos cristãos não católicos na celebração eucarística, por exemplo, é um fato mencionado pelo documento. De fato, urge que a comunhão da Eucaristia se estenda à comunhão dos corações e das vidas, pois, segundo o papa, “o vínculo intrínseco existente entre a Eucaristia e a unidade da Igreja nos faz desejar ardentemente o dia em que poderemos celebrar, juntamente com todos os que crêem em Cristo, a divina Eucaristia e exprimir assim visivelmente aquela plena unidade que Cristo quis para os seus discípulos" ( $S C$, n. 56). Entretanto, não podemos pretender que por ecumenismo o documento esteja se referindo a uma macro religião, a um "policristianismo" único e de alcance global. Participar da Eucaristia implica absoluta comunhão de crenças, e isso supõe uma total adesão não somente ao ideal religioso - o cristianismo, neste caso - mas à tradição cultural, à fé professada pelos dogmas, ao pertencimento na vivência eclesial. Nesse sentido, os adeptos de outras igrejas cristãs, ainda que convidados à celebração da fé em Cristo, que é una, sedimentada em sua Paixão, Morte e Ressurreição, são orientados a se absterem da comunhão eucarística, pelo fato de não estarem em plena comunhão com a Igreja Católica.

\footnotetext{
7 Leonardo Boff: Teólogo, escritor e um dos principais expoentes da Teologia da Libertação, em entrevista à Cláudia, com publicação em 19/11/2007.

Disponível em http://claudia.abril.com.br/materia/polmicas-na-igreja2397/?p=/comporta mento/atualidades
} 
A relação entre fé e meios de comunicação também se torna alvo da atenção dos padres sinodais. Em tempo de globalização - ou de pós-globalização, como denominam os mais otimistas -, o conservadorismo que rejeita a utilização de novas tecnologias nas instâncias religiosas não mais se sustenta. Aliás, muitos sinais têm apontado para o fato de que parece não ser esse o caminho percorrido tanto por Bento XVI - recentemente inaugurando seu twitter - quanto por toda a Igreja, na qual temas como comunicação e mídias ganham cada vez mais enfoque. Ainda sobre esse assunto, a preocupação com os migrantes e sua integração na celebração da fé católica não somente evidencia o estreitamento das relações entre os povos, mas o caráter caritativo da Igreja primitiva, herdado do judaísmo, para a qual o primeiro objeto do serviço da caridade eram os estrangeiros, as viúvas e os órfãos.

\section{Algumas Questões PolÊMicas E Suas Relações Dialógicas}

Ao refletirmos sobre o discurso religioso, uma dificuldade que se nos apresenta é a consciência de que não podemos nos ater apenas ao material, ao palpável, mas também ao que não se exprime por palavras, ao inefável, o que é, por sua vez, o que traz o encantamento de tal discurso e mantém viva a fé. Daí, muitas vezes, a dificuldade em entender o fundamento do discurso religioso, pois ele se pauta no sagrado e na fé e, se nos falta percepção desse sentimento do sagrado, foge-nos a essência de tal discurso. Essa ideia do mistério tem relação com a própria Eucaristia, como nos mostra Bento XVI.

"Mistério da fé!": com esta exclamação pronunciada logo a seguir às palavras da consagração, o sacerdote proclama o mistério celebrado e manifesta o seu enlevo diante da conversão substancial do pão e do vinho no corpo e no sangue do Senhor Jesus, realidade esta que ultrapassa toda a compreensão humana. Com efeito, a Eucaristia é por excelência "mistério da fé": "É o resumo e a súmula da nossa fé". A fé da Igreja é essencialmente fé eucarística e alimenta-se, de modo particular, à mesa da Eucaristia. [...] "A fé exprime-se no rito e este revigora e fortifica a fé"

Por isso, o sacramento do altar está sempre no centro da vida eclesial; "graças à Eucaristia, a Igreja renasce sempre de novo!"10 $[\ldots ..] .(S C \text { n.6 })^{11}$

${ }^{8}$ Catecismo da Igreja Católica, 1327. (Nota do autor)

9 Propositio 16. (Nota do autor)

10 Bento XVI, Homilia na tomada de posse da Cátedra de Roma (7 de Maio de 2005): AAS97 (2005), 752. (Nota do autor)

${ }^{11}$ Quando diz: a Eucaristia é por excelência "mistério da fé": "É o resumo e a súmula da nossa fé”, o autor recorre a uma Propositio ${ }^{11}$, como ocorrerá ao longo de todo o texto. Por propositio (plural: propositii), nos referimos à "formulação linguística de um juízo. Tradicionalmente, considera-se o juízo como um ato mental e a proposição como sua expressão 
Pensar um discurso tão consolidado como o religioso, em especial o católico, é, antes, pensar na luta pelo poder do discurso ${ }^{12}$. O que não é, certamente, característica exclusiva do discurso em questão, visto que cada indivíduo tem seu lugar, e cada lugar tem seus contextos e propósitos próprios e que, na interação social, entram em contato com muitos outros discursos que também concebem o mundo segundo seus critérios. Aí, fundam-se as relações dialógicas das quais nenhum discurso pode se privar.

A escolha de um determinado discurso implica entender a realidade concebida sob tal prisma e acatar seus paradigmas, as premissas pelas quais tal concepção é feita; é preciso compreender o “mistério da fé”. Não há como mergulhar num discurso sem entender os pontos que o norteiam.

\subsection{A EUCARISTIA E A VERDADE NO CRISTIANISMO}

Já na introdução da Sacramentum Caritatis, Bento XVI nos apresenta a Eucaristia como "O alimento da verdade".

[...] Uma vez que só a verdade nos pode tornar verdadeiramente livres (Jo 8, 36), Cristo faz-Se alimento de Verdade para nós. Com agudo conhecimento da realidade humana, Santo Agostinho pôs em evidência como o homem se move espontaneamente, e não constrangido, quando encontra algo que o atrai e nele suscita desejo. Perguntando-se ele, uma vez, sobre o que poderia em última análise mover o homem no seu íntimo, o santo bispo exclama: "Que pode a alma desejar mais ardentemente do que a verdade?"13[...]. No sacramento da Eucaristia, Jesus mostra-nos de modo particular a verdade do amor, que é a própria essência de Deus [...]. Por isso a Igreja, que encontra na Eucaristia o seu centro vital, esforça-se constantemente por anunciar a todos, em tempo propício e fora

linguística” (Japiassú/ Marcondes, 2001, p. 95). Ou seja, trata-se da manifestação antecipada de um juízo futuro, uma pró-posição, a assumência de posição em relação ao que está por vir. Em Sacramentum Caritatis, a constante menção às proposições da assembleia sinodal, ordenadas numericamente e mencionadas em notas de rodapé, acentua o caráter colegiado do texto, construído a partir de um intercruzamento de ideias e posicionamentos diversos - muitas vezes distintos entre si. Geralmente, antes da aprovação de suas diretrizes finais, um documento como este é apresentado sob a forma de proposições - por sua vez submetidas à votação e à chancela da maioria qualificada (composta por $2 / 3$ ou 3/5 do todo). Em sua redação final, seu texto trará, como referências sempre presentes, as proposições efetivamente integradas ao seu discurso. Esta permanecerá como uma das grandes marcas do discurso coletivo: a palavra lançada e novamente recolhida (dialogos), a polifonia dos sujeitos (intersubjetividade).

${ }^{12} \mathrm{O}$ discurso não é simplesmente aquilo que traduz as lutas ou os sistemas de dominação, mas aquilo por que, pelo que se luta, o poder do qual nos queremos apoderar. (Foucault, 2008, p.10)

${ }^{13}$ Santo Agostinho, In Iohannis Evangelium Tractatus, 26, 5: PL 35, 1609. (Nota do autor) 
dele (opportune, importune: cf. $2 \operatorname{Tm} 4,2$ ), que Deus é amor ${ }^{14}$. Exatamente porque Cristo Se fez alimento de Verdade para nós, a Igreja dirige-se ao homem convidando-o a acolher livremente o dom de Deus. (SC n.2)

Aqui, se faz ouvir a voz de Bento XVI, que em outros discursos já se pronunciara a respeito da questão da verdade na religião. Assim, retoma o próprio discurso, bem como o de Santo Agostinho, pautado nas Sagradas Escrituras, a fim de fundamentar a sua doutrina e manter, dessa forma, a ideia de coerência e continuidade na Tradição da Igreja Católica.

Dois exemplos de discursos próprios retomados por Bento XVI sobre a verdade são o da carta encíclica Caritas in Veritate e o de uma entrevista concedida por ele durante o voo rumo à Jornada Mundial da Juventude, em Madri. $\mathrm{Na}$ carta encíclica, ele afirma que

[...] Jesus Cristo purifica e liberta das nossas carências humanas a busca do amor e da verdade e desvenda-nos, em plenitude, a iniciativa de amor e o projeto de vida verdadeira que Deus preparou para nós. Em Cristo, a caridade na verdade torna-se o Rosto da sua Pessoa, uma vocação a nós dirigida para amarmos os nossos irmãos na verdade do seu projeto. De fato, Ele mesmo é a Verdade (cf. Jo 14, 6) (Bento XVI, 2009, n.1).

Já na entrevista, diante da pergunta de um jornalista sobre se não seria um ato de intolerância apresentar Cristo como a verdade, Bento XVI responde que a “verdade não se impõe, ela só pode ser acolhida na liberdade”. Destaca, ainda, que "a relação entre verdade e intolerância, monoteísmo e incapacidade de diálogo com os outros, é um tema que com frequência volta ao debate sobre o cristianismo de hoje", visto que, no passado, houve abusos tanto em relação à verdade quanto ao monoteísmo, mas afirma que hoje a realidade é outra, "pois a verdade só é possível na liberdade" 15 . A pergunta do jornalista se fundamenta nos efeitos que enunciados como "Senhor Jesus, caminho, verdade e vida" (Jo 14, 6) ou "Jesus Cristo é a Verdade feita Pessoa" podem surtir em quem não partilha da mesma crença. Mas Bento XVI rechaça essa ideia de imposição de uma verdade ao dizer que ela só pode ser aceita na liberdade. Assim, na exortação, retoma o discurso da entrevista ao final do trecho citado: "a Igreja dirige-se ao homem convidando-o a acolher

14 Ver Bento XVI, Discurso aos membros do Conselho Ordinário da Secretaria Geral do Sínodo dos Bispos (1 de Junho de 2006): L'Osservatore Romano (ed. port. de 8/VI/2006), 237. (Nota do autor)

${ }^{15}$ Entrevista concedida pelo papa durante o voo rumo à Jornada Mundial da Juventude, em Madri. Disponível em http://www.zenit.org/article-28623?1=portuguese, com acesso em 20/8/2011 às $13 \mathrm{~h} 28$. 
livremente o dom de Deus", o que, por sua vez, fundamenta-se nas palavras de João, citadas no início do parágrafo n.2 - Jo 8, 36

Essa questão da verdade já fora, ainda, tema de um debate entre o então cardeal Ratzinger e o filósofo Paolo D’Arcais ${ }^{16}$, quando refletiram sobre a pretensão

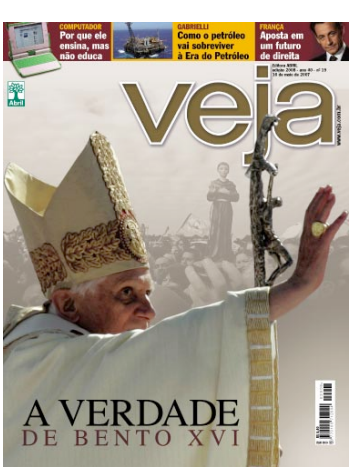

verdade. da verdade do cristianismo e a controvérsia acerca das provas da verdade da religião. Se expandirmos este diálogo para os meios de comunicação, notaremos que a questão da verdade é ligada, constantemente, à religião, como nos mostra esta capa de revista ${ }^{17}$, que coloca Bento XVI como um portador da verdade. Podemos notar, ainda, que, embora ele seja o portador da verdade de uma instituição a qual representa, o enunciado da capa leva-nos a imaginá-lo como o “dono” de tal

Diante de questões como essas, verificamos que a Sacramentum Caritatis mostra uma relação dialógica tanto com a própria Igreja e sua tradição como com o mundo. E essas vozes aparecem no discurso desta exortação que, como documento norteador para a Igreja, é um texto que responde a questões que estão circulando na sociedade, no contexto atual. Assim como responde, tal discurso também suscita muitas respostas.

Em Gêneros do Discurso, Bakhtin (2006a) destaca algumas propriedades que caracterizam um enunciado, as quais, no texto em questão, podem ser observadas: a alternância dos sujeitos e a conclusibilidade (além da escolha do gênero discursivo). A alternância dos sujeitos do discurso define limites precisos para cada enunciado nos diversos campos da atividade humana. Assim, todo enunciado tem um princípio e um fim absoluto:

antes do seu início, os enunciados de outros; depois do seu término, os enunciados responsivos de outros (ou ao menos uma compreensão ativamente responsiva silenciosa do outro ou, por último, uma ação responsiva baseada nessa compreensão). O falante termina o seu enunciado para passar a palavra ao outro ou dar lugar à sua compreensão ativamente responsiva (Bakhtin, 2006a, p.275).

Além dessa alternância dos sujeitos, Bakhtin nos apresenta outra peculiaridade do enunciado que é a conclusibilidade. Esta é um tipo interno da

\footnotetext{
16 Trata-se esta obra de um debate realizado, em 21 de fevereiro de 2000, entre o então cardeal Joseph Ratzinger e o filósofo ateu Paolo Flores d'Arcais, com o intrigante tema "Deus existe?".

${ }_{17}$ Revista Veja, edição 2008, de 16 de maio de 2007, editora Abril.
} 
alternância dos sujeitos e pode ocorrer quando se tem a impressão de que o falante (ou escritor) já disse tudo o que pretendia, em determinada situação. Assim, "o primeiro e mais importante critério de conclusibilidade do enunciado é a possibilidade de responder a ele, em termos mais precisos e amplos de ocupar em relação a ele uma posição responsiva" (Bakhtin, 2006a, p.280). Portanto, concluído o enunciado do falante, pode-se tomar uma posição, em relação a ele, avaliando-o em seu conjunto.

Como já afirmado, esta exortação apostólica é um resumo apresentado pelo papa Bento XVI das questões discutidas no Sínodo dos Bispos sobre a Eucaristia, em 2005. É interessante notar que o autor faz uma marcação distinta das vozes que enunciam ao longo da exortação. Assim, ele enuncia em $1^{\mathrm{a}}$ pessoa: Desejo chamar a atenção, Quero sublinhar aqui a relevância (n.19), e, em outros momentos, enuncia: Os padres sinodais afirmaram (n.20), Os padres sinodais quiseram sublinhar (n.24). Além disso, para destacar a sintonia entre o seu discurso e o dos padres sinodais, constrói enunciações como: Desejo sobretudo recomendar, acolhendo o voto dos padres sinodais (n.5); Desejo sublinhar aqui alguns elementos, assinalados pelos padres sinodais (n.16); Devemos interrogar-nos como sugeriram os padres sinodais (n.17), Nesta linha, queria, juntamente com os padres sinodais (n.32); Neste contexto, desejo dar voz àquilo que os padres referiram (n.87) ou usa a $3^{\text {a }}$ pessoa do plural, ressaltando a ideia de colegialidade, Constatamos - é certo - que (n.20). Notamos, ainda, que no parágrafo 17, ao usar a expressão “devemos interrogar-nos", ele se coloca também como um interlocutor que acata as decisões.

Esses exemplos de como Bento XVI retoma o discurso dos padres sinodais e o propósito desta exortação - uma súmula que conclui, arremata os temas discutidos no Sínodo - vão ao encontro do que Bakhtin nos apresenta sobre o discurso de outrem: o "discurso citado é o discurso no discurso, a enunciação na enunciação, mas é, ao mesmo tempo, um discurso sobre o discurso, uma enunciação sobre a enunciação" (Bakhtin, 2006b, p.150). Assim, ele apreende a palavra alheia e a usa em seu discurso, considerando-se que "não é um ser mudo, privado da palavra, mas ao contrário um ser cheio de palavras interiores" (idem, p.153-154).

Bakhtin nos aponta o caminho para as relações dialógicas, nas quais os sentidos são gerados na convivência com o diferente. Assim, o discurso é constituído na relação com os discursos alheios. E "esse trabalho dialógico, responsivo, centrado na alteridade, está sempre prenhe de perspectivas e buscas por completudes de sentidos, de identidades, de relações sociais, sempre 
inconclusas" (GEGe, 2009, p.51-52). Entendemos, por isso, que este texto também é uma atividade que responde a outros textos e dialoga, dessa forma, com outros sujeitos e, consequentemente, suscita outros discursos e outras consciências (na explicação, há apenas uma consciência; na compreensão, duas.). A palavra "avança cada vez mais à procura dessa compreensão responsiva. A palavra quer ser ouvida, entendida, respondida na relação dialógica” (GEGe, 2010, p.85). Afinal, é na resposta que a compreensão conhece seu amadurecimento. Elas estão indissoluvelmente ligadas (Bakhtin, 1988).

Quando uma questão é proposta como tema de uma assembléia sinodal, podemos entendê-la como sendo urgente de reflexão pela Igreja, ou seja, uma questão que está se ressignificando nos diferentes contextos sociais. Logo, a escolha do objeto de reflexão já prevê a aproximação com o que está repleto de ressonância da voz de outro; cercado, envolto em outros discursos. Do outro de onde o discurso procede e, especialmente, do outro a quem ele se dirige.

Todo discurso é orientado para a resposta e ele não pode esquivar-se à influência profunda do discurso da resposta antecipada. O discurso vivo e corrente está determinado pelo discurso-resposta futuro: ele é que provoca esta resposta, pressente-a e baseia-se nela. Ao se construir no "já-dito", o discurso é orientado ao mesmo tempo para o discurso-resposta que ainda não foi dito, discurso, porém, que foi solicitado a surgir e que já era esperado (Bakhtin, 1988, p.89).

Entendemos que "todo discurso que fale de qualquer objeto não está voltado para a realidade em si, mas para os discursos que a circundam" (Fiorin, 2008, p.19). Logo, a palavra está sempre em diálogo com outras palavras, constituindo-se a partir delas e, consequentemente, gerando muitas outras. E esses discursos que circundam a realidade representam uma posição ideológica.

Assim, podemos supor que, através de seu discurso, Bento XVI, representante de uma igreja tradicional, expressa a ideologia dessa igreja, considerada uma ideologia oficial, mas que, muitas vezes, está destoada das ideologias do cotidiano ${ }^{18}$ de seus fiéis. Por isso, nesta análise, destacamos alguns temas da exortação que foram considerados bastante controversos, que dizem respeito à vida dos fiéis e que surtiram muitas respostas tanto de concordância como de discordância.

${ }^{18}$ Como já ressaltamos, a concepção bakhtiniana compreende uma ideologia oficial e uma do cotidiano: "A ideologia oficial é entendida como relativamente dominante, procurando implantar uma concepção única de produção de mundo. A ideologia do cotidiano é considerada como a que brota e é constituída nos encontros casuais e fortuitos, no lugar do nascedouro dos sistemas de referência, na proximidade social com as condições de produção e reprodução da vida”. (MIOTELLO, 2008, p.168-169) 
Inicialmente, para entendermos a questão da indissolubilidade do casamento (um tema polêmico nesta carta), é interessante entender, antes, a questão do “indissolúvel”, no contexto da Igreja e das Sagradas Escrituras.

A Eucaristia é, pois, constitutiva do ser e do agir da Igreja. Por isso, a antiguidade cristã designava com as mesmas palavras - corpus Christi - o corpo nascido da Virgem Maria, o corpo eucarístico e o corpo eclesial de Cristo $^{19}$. Bem atestado na tradição, este dado faz crescer em nós a consciência da indissolubilidade entre Cristo e a Igreja. [...] O servo de Deus João Paulo II, na sua Encíclica Ecclesia de Eucharistia, tinha já chamado a atenção para a relação entre Eucaristia e communio: falou do memorial de Cristo como sendo a "suprema manifestação sacramental da comunhão na Igreja" 20 . A unidade da comunhão eclesial revela-se, concretamente, nas comunidades cristãs e renova-se no ato eucarístico que as une e diferencia em Igrejas particulares, "in quibus et ex quibus una et unica Ecclesia catholica exsistit - nas quais e pelas quais existe a Igreja Católica, una e única" ${ }^{21}$. [...]. De fato, "a unicidade e indivisibilidade do corpo eucarístico do Senhor implicam a unicidade do seu corpo místico, que é a Igreja una e indivisível [.... ${ }^{22}$." (SC n.15)

A Eucaristia, sacramento da caridade, apresenta uma relação particular com o amor do homem e da mulher unidos em matrimônio. [...] Várias vezes o Papa João Paulo II teve ocasião de afirmar o caráter esponsal da Eucaristia e a sua relação peculiar com o sacramento do matrimônio: "A Eucaristia é o sacramento da nossa redenção. É o sacramento do Esposo, da Esposa"23. [...]. Esta corrobora de forma inexaurível a unidade e o amor indissolúveis de cada matrimônio cristão. Neste, em virtude do sacramento, o vínculo conjugal está intrinsecamente ligado com a união eucarística entre Cristo esposo e a Igreja esposa ( $E f 5,31-32)$. [...] Na teologia paulina, o amor esponsal é sinal sacramental do amor de Cristo pela sua Igreja, um amor que tem o seu ponto culminante na cruz, expressão das suas "núpcias" com a humanidade e, ao mesmo tempo, origem e centro da Eucaristia. Por isso, a Igreja manifesta uma particular solidariedade espiritual a todos aqueles que fundaram a sua família sobre o sacramento do Matrimônio ${ }^{24}$. A família - igreja doméstica ${ }^{25}$ - é um âmbito primário da vida da Igreja, especialmente

\footnotetext{
${ }^{19}$ Ver Propositio 5. (Nota do autor)

${ }^{20}$ N. 38: $A A S 95$ (2003), 458. (Nota do autor)

${ }^{21}$ Conc. Ecum. Vat. II, Const. dogm. sobre a Igreja Lumen gentium, 23. (Nota do autor)

${ }_{22}$ Congr. para a Doutrina da Fé, Carta sobre alguns aspectos da Igreja entendida como comunhão Communionis notio (28 de Maio de 1992), 11: AAS 85 (1993), 844-845. (Nota do autor)
}

${ }^{23}$ Carta ap. Mulieris dignitatem (15 de Agosto de 1988), 26: AAS 80 (1988), 1715-1716. (Nota do autor)

24 Ver Propositio 8. (Nota do autor)

25 Ver Conc. Ecum. Vat. II, Const. dogm. sobre a Igreja Lumen gentium, 11. (Nota do autor) 
pelo papel decisivo que tem na educação cristã dos filhos ${ }^{26}$. Neste contexto, o Sínodo recomendou também o reconhecimento da missão singular que tem a mulher na família e na sociedade, missão esta que há de ser protegida, salvaguardada e promovida ${ }^{27}$. A sua dimensão de esposa e mãe constitui uma realidade imprescindível, que nunca deve ser desprezada. (SC n.27)

[...] O vínculo fiel, indissolúvel e exclusivo que une Cristo e a Igreja e tem expressão sacramental na Eucaristia, está de harmonia com o dado antropológico primordial segundo o qual o homem deve unir-se de modo definitivo com uma só mulher, e viceversa $(G n 2,24 ; M t 19,5)[\ldots .] ..(S C$ n.28)

Em meio a essa questão da indissolubilidade do matrimônio, uma inquietação que surge no interlocutor diante das palavras do papa em passagens como "o homem deve unir-se de modo definitivo com uma só mulher, e vice-versa" ou "A Eucaristia [...] apresenta uma relação particular com o amor do homem e da mulher unidos em matrimônio", tanto aqui como em outros fragmentos, nos recorda que na sociedade convivem também as relações de amor homossexuais. Há uma voz que clama pelo reconhecimento do casamento homossexual. Trata-se de um apagamento que o discurso da exortação faz, talvez por entender que este é um assunto que não deve ser tratado de forma superficial. Mas como a palavra está aberta, recentemente, Bento XVI foi alvo de duras críticas porque teria dito que o casamento gay é uma ameaça à humanidade. Na verdade, ele havia falado em favor da família, "apoiada no matrimônio entre homem e mulher" 28 e não fez referência ao casamento gay. Mas suas palavras suscitaram a especulação, a vontade de que ele se manifestasse sobre o homossexualismo; uma crítica à omissão da Igreja omissão esta que contribui, muitas vezes, para que alguns fiéis alimentem um preconceito em relação ao homossexualismo que contraria os princípios de amor ao próximo que a própria Igreja propaga.

A questão da indissolubilidade que a Igreja nos coloca, sob o signo da Eucaristia, representa, assim, a relação entre Cristo e a Igreja e, consequentemente,

${ }^{26}$ Ver Propositio 8. (Nota do autor)

27 Ver João Paulo II, Carta ap. Mulieris dignitatem (15 de Agosto de 1988): AAS 80 (1988), 16531729; Congr. para a Doutrina da Fé, Carta aos bispos da Igreja Católica sobre a colaboração do homem e da mulher na Igreja e no mundo (31 de Maio de 2004): AAS 96 (2004), 671-687. (Nota do autor)

${ }^{28}$ Pesquisado em http://www.acidigital.com/noticia.php?id=23020. Discurso do papa, na íntegra, disponível em:

http://www.vatican.va/holy father/benedict xvi/speeches/2012/january/documents/hf beni_spe_20120109_di plomatic-corps_po.html. Acesso em 22/01/2012 às $10 h 45$ 
entre Igreja/Eucaristia e família/matrimônio. Tal parâmetro encontra uma contrapalavra na análise de Leonardo Boff ${ }^{29}$.

[...]. [A exortação] fala dos divorciados que devem permanecer na Igreja e sentir-se como seus membros, mas por causa da ruptura do laço matrimonial indissolúvel não podem aproximar-se da eucaristia. O argumento que se aduz é: o casamento é símbolo do matrimônio que Deus celebrou indissoluvelmente com a Igreja. Como os divorciados e os que estão em segundas núpcias violaram a indissolubilidade não podem receber o sacramento que representa essa indissolubilidade. Eu considero a argumentação inconsistente por duas razões. Primeira: o vínculo da Igreja para com Cristo não é indissolúvel. A Igreja é também pecadora. Há uma tradição antiga que chama a Igreja de "casta meretriz". A cada noite ela cai em pecado e a cada manhã Cristo a limpa, lava e renova o vínculo com ela. O então professor Joseph Ratzinger (o atual papa Bento XVI), em suas aulas e escritos, se referia muitas vezes a essa situação ambígua da Igreja. Então, o argumento para os divorciados de não terem acesso à eucaristia não se sustenta. Segunda razão: para Jesus, a ruptura e o fracasso, possíveis à condição humana, nunca têm a última palavra, mas a misericórdia e o perdão. A Igreja não mostra misericórdia como Jesus. Por isso, acaba discriminando os divorciados. Algo semelhante deve-se dizer sobre as uniões homossexuais. Se há amor entre as pessoas, então há algo divino, pois Deus é amor. Deve-se respeitar o percurso dos homossexuais e entendê-los à luz de Deus. E combater a discriminação contra eles.

Podemos entender que o discurso de Bento XVI antecipa uma resposta a essas contrapalavras. Isso é perceptível pelo uso de discursos diretos, destacados entre aspas, das propostas dos bispos, de João Paulo II, do Concílio Vaticano II, o que dá maior sustentação a sua fundamentação, por sua vez, baseada em documentos da Tradição da Igreja Católica e em textos bíblicos. Demonstra, assim, que a Igreja continua firme em suas proposições, mesmo diante de questões tão presentes no seu contexto, de questionamentos que insistem em solicitar uma renovação. Pelo que vimos, esses apelos sociais não encontram ressonância no colegiado da Igreja. Mas, se tais assuntos polêmicos foram postos em pauta na assembleia é porque estão fervilhando nos diversos contextos em que a Igreja se insere. Assim, a Igreja responde a esses discursos ao reafirmar a sua postura e, ao mesmo tempo, encontra muitas respostas às suas proposições, tanto nas palavras de um estudioso como na ação dos fiéis diante de tais assuntos.

O uso de recursos como o discurso direto dos documentos referidos demonstra a preocupação do autor em mostrar, ainda, a coerência da Tradição da Igreja e apagar a possível ideia de ruptura, a qual muitos apontam que houve com o Concílio Vaticano II. Aliás, Bento XVI, desde a sua época de cardeal, teve a preocupação de ressaltar o fato de que na Igreja Católica não há ruptura, mas

29 Leonardo Boff: Teólogo, escritor e um dos principais expoentes da Teologia da Libertação, em entrevista à Cláudia, com publicação em 19/11/2007. Disponível em: http://claudia.abril.com.br/materia/polmicas-na-igreja2397/?p=/comporta mento/atualidades 
continuidade. As escolhas das suas citações procuram reforçar essa tese. No trecho a seguir, ele retoma esse caráter de continuidade, em sua análise sobre a reforma litúrgica do Concílio Vaticano II dentro da Tradição da Igreja.

[...] Desde as múltiplas formas dos primeiros séculos, que resplandecem ainda nos ritos das Antigas Igrejas do Oriente, até a difusão do rito romano; desde as indicações claras do Concílio de Trento e do Missal de São Pio V até a renovação litúrgica querida pelo Concílio Vaticano II: em cada etapa da história da Igreja, a celebração eucarística, enquanto fonte e ápice da sua vida e missão, resplandece no rito litúrgico em toda a sua multiforme riqueza. [...] De modo particular, os padres sinodais reconheceram e reafirmaram o benéfico influxo que teve, na vida da Igreja, a reforma litúrgica atuada a partir do Concílio Ecumênico Vaticano $\mathrm{II}^{30}$. O Sínodo dos Bispos pôde avaliar o acolhimento que a mesma teve depois da assembleia conciliar; inúmeros foram os elogios; como lá se disse, as dificuldades e alguns abusos assinalados não podem ofuscar a excelência e a validade da referida renovação litúrgica, que contém riquezas ainda não plenamente exploradas. Trata-se, em concreto, de ler as mudanças queridas pelo Concílio dentro da unidade que caracteriza o desenvolvimento histórico do próprio rito, sem introduzir artificiosas rupturas ${ }^{31}$. $(S C$ n.3)

Ao final do trecho, na expressão "abusos assinalados”, reconhecemos a convicção do Sínodo em afirmar que houve desvios no entendimento da "reforma litúrgica” pregada pelo Concílio Vaticano $\mathrm{II}^{32}$. Isso Bento XVI já havia afirmado em outras publicações. Podemos entender, assim, que tal discurso é reafirmado para se defender do rótulo do conservadorismo, antecipando as vozes sociais que certamente assim identificarão tal documento. Algumas vozes radicais, como podemos notar:"E foi assim que no ano da graça de 2007 foi colocada a pedra tumular sobre o Concílio Vaticano II [...]. A Exortação pós Sinodal Sacramentum Caritatis, publicada hoje, não é senão o selo definitivo de Bento XVI à grande Restauração"33.

\footnotetext{
${ }^{30}$ Ver Propositio 2. (Nota do autor)

${ }^{31}$ Aludo aqui à necessidade duma hermenêutica da continuidade mesmo no que diz respeito a uma correta leitura do desenvolvimento litúrgico depois do Concílio Vaticano II: cf. Bento XVI, Discurso à Cúria Romana (22 de Dezembro de 2005): AAS 98 (2006), 44-45. (Nota do autor)
}

${ }^{32}$ Em outras publicações do autor, é possível entender que esses "abusos assinalados" são creditados à interpretação, em especial, que a Teologia da Libertação deu ao documento do referido Concílio.

33 Paolo Giorgi, em seu artigo "A Grande Intervenção" in ABRIL Info ON LINE . 13 de Março de 2007 http://www.aprileonline.info/2189/la-grande-ingerenza. Publicado em Orlando Fedeli -

"Reações a Exortação Apostólica Sacramentum Caritatis do Papa Bento XVI" MONTFORT Associação Cultural http://www.montfort.org.br/index.php?secao=veritas\&subsecao=igreja\&artigo=reacoes sacra mentum\&lang=bra Online, $14 / 12 / 2012$ às $07: 27 \mathrm{~h}$ 
Retomando o parágrafo 29, este reforça a questão de que o matrimônio, para a Igreja, é indissolúvel e causa polêmica ao se referir ao divórcio.

\section{Eucaristia e indissolubilidade do Matrimônio}

Se a Eucaristia exprime a irreversibilidade do amor de Deus em Cristo pela sua Igreja, compreende-se por que motivo a mesma implique, relativamente ao sacramento do Matrimônio, aquela indissolubilidade a que todo o amor verdadeiro não pode deixar de anelar ${ }^{34}$. Por isso, é mais que justificada a atenção pastoral que o Sínodo reservou às dolorosas situações em que se encontram não poucos fiéis que, depois de ter celebrado o sacramento do Matrimônio, se divorciaram e contraíram novas núpcias. Trata-se dum problema pastoral espinhoso e complexo, uma verdadeira praga do ambiente social contemporâneo que vai progressivamente corroendo os próprios ambientes católicos. Os pastores, por amor da verdade, são obrigados a discernir bem as diferentes situações, para ajudar espiritualmente e de modo adequado os fiéis implicados ${ }^{35}$. [...]. (n.29) (grifos nossos)

Uma controvérsia desse trecho de parágrafo está no uso de "praga” para designar uma segunda união (grifos). Segundo alguns estudos, houve, na verdade, um erro ao traduzirem "plaga”, do latim, por "praga”, em português, como afirma D. Rafael Cifuentes ${ }^{36}$.

No texto original, em latim, plaga pode ser traduzida também como chaga, ferimento, flagelo, tapa. A tradução inglesa utilizou a palavra scourge que significa flagelo. Seja qual for o termo que se utilize para a tradução, fica claro no contexto que o papa sublinha que os divorciados e recasados não podem ser considerados como uma "praga": eles são amados como filhos que a Igreja cuida com "especial solicitude".

Devemos reconhecer que há um pré-conceito em relação a esse discurso, a esse sujeito, o que faz com que muitas análises busquem expressões como essa ("praga”) apenas para reforçar uma tese já formulada antes mesmo da leitura. Como afirma Paden (2001): "Quando o objeto da interpretação chega vestido em linguagem, a interpretação já começou” (p.210).

Outra polêmica ocorre na recomendação dada, ao final desse parágrafo:

[...] Enfim, caso não seja reconhecida a nulidade do vínculo matrimonial e se verifiquem condições objetivas que tornam realmente irreversível a convivência, a Igreja encoraja

34 Ver Catecismo da Igreja Católica, 1640. (Nota do autor)

35 Ver João Paulo II, Exort. ap. pós-sinodal Familiaris consortio (22 de Novembro de 1981), 84: AAS 74 (1982), 184-186; Congr. para a Doutrina da Fé, Carta aos bispos da Igreja Católica acerca da recepção da comunhão eucarística pelos fiéis divorciados re-casados Annus internationalis familiæ (14 de Setembro de 1994): AAS 86 (1994), 974-979. (Nota do autor)

${ }^{36}$ D. Rafael Cifuentes: presidente da Comissão Episcopal Pastoral para a Vida e a Família, da CNBB, em entrevista à Cláudia, com publicação em 19/11/2007. Disponível em http://claudia.abril.com.br/materia/polmi cas-na-igreja-2397/?p=/comportamento/atualidades 
estes fiéis a esforçarem-se por viver a sua relação segundo as exigências da lei de Deus, como amigos, como irmão e irmã; deste modo poderão novamente abeirar-se da mesa eucarística, com os cuidados previstos por uma comprovada prática eclesial. Para que tal caminho se torne possível e dê frutos, deve ser apoiado pela ajuda dos pastores e por adequadas iniciativas eclesiais, evitando, em todo o caso, de abençoar estas relações para que não surjam entre os fiéis confusões acerca do valor do matrimônio ${ }^{37}$. (SC n.29)

Vejamos algumas respostas que representam, por conseguinte, a percepção de muitos interlocutores diante do texto:

[...]. Boa parte dos fiéis não se importa com esse tipo de orientação doutrinária. Se eles quiserem comungar, vão comungar. Nesse contexto, os católicos mais engajados carregam uma contradição, porque não se sentem parte da comunidade. A eucaristia é o ponto central de uma missa. A Igreja Católica aceita o divorciado e o recasado na missa, mas os proíbe de ter acesso à comunhão. É igual a convidar um casal para uma festa em sua casa, mas proibi-lo de comer o bolo. Quando a Igreja Católica reafirma a indissolubilidade do matrimônio e o papel da mulher como esposa e mãe, está fechando os olhos para graves problemas do mundo contemporâneo. Um deles é a violência doméstica. A Igreja Católica prefere que essas mulheres continuem apanhando dos maridos em vez de lhes oferecer a possibilidade de reconstruir a vida. Mais uma vez a instituição do casamento é mais importante do que o respeito à dignidade da vida humana - nesse caso, a vida da mulher ${ }^{38}$.

Ele é um atentado aos direitos humanos e ao desejo. Se o casamento não está bom, por que suportá-lo? A Igreja nunca levou em consideração o desejo feminino. Os casamentos duravam por causa da resignação histórica das mulheres. Ao afirmar que "o segundo casamento é uma praga”, o papa desconsidera não só o desejo, como também as outras culturas e religiões, que encaram o mesmo assunto de forma diferente. Há uma grande contradição nesta exortação: se Deus é amor, pressupõe-se que haja solidariedade e compreensão. Mas como sobreviver a um casamento que não está bom? O amor no casamento não é incondicional. Só o amor divino é incondicional. Ao pregar que um casamento não pode ser desfeito, a Igreja quer comparar o amor divino ao amor conjugal - ou seja, a Igreja quer que o amor conjugal seja incondicional, que tudo seja aceito. $\mathrm{O}$ amor de pai para filho pode ser assim, mas entre marido e mulher nem sempre39.

Tais palavras encontram, também, respostas convergentes.

A não-comunhão não deixa de ser um cerceamento. Mas há dois fatores. Primeiro: a Igreja não fecha as portas, totalmente, para os divorciados. Segundo: as pessoas andam muito mal no sentido emocional. O papa teve uma atitude corajosa ao destoar do obaoba que defende o relacionamento imediato e a sensualização do casamento (que culminam com o divórcio) como a chave para se livrar do mal-estar emocional. Para ele,

37 Ver Propositio., 40. (Nota do autor)

38 Regina Jurkewicz. Professora de teologia, pesquisadora e coordenadora-executiva da ONG Católicas pelo Direito de Decidir, em entrevista à Cláudia, com publicação em 19/11/2007. Disponível em

http://claudia.abril.com.br/materia/polmicas-na-igreja-2397/?p=/comportamento/atualidades

39 Rodrigo Pereira. Advogado, professor da PUC/MG e presidente do Instituto Brasileiro de Direito da Família, em entrevista à Cláudia, com publicação em 19/11/2007. Disponível em http://claudia.abril.com.br/materia/polmicas-na-igreja-2397/?p=/comportamento/atualidades 
a indissolubilidade do casamento seria igual à indissolubilidade da maternidade e da paternidade. Se o casamento for indissolúvel, talvez deixe de ser sexualizado como é hoje. O que move o Papa é que o ser humano precisa de parâmetros. As pessoas têm que ter motivos sérios para casar. Ao dizer que o segundo casamento é uma "praga", quis dizer que se essa "praga" for estancada agora, os jovens vão pensar 15 vezes antes de casar. E é nos jovens que ele está pensando ao afirmar isso. Se você errar, tem que arcar com seu erro40.

Se, por um lado, entendemos o quanto essas contrapalavras estão ligadas ao contexto atual e o quanto a Igreja parece destoada desse contexto, por outro, não podemos acusá-la de incoerência. A Igreja Católica vem se mantendo por séculos segundo princípios que considera inegociáveis. Não é uma instituição que vai mudar os seus dogmas de acordo com os novos contextos que se apresentam, mas reafirmá-los, mesmo diante de controvérsias. Se acusada de propagar um discurso de conservadorismo e excesso de rigor, podemos entender tais discursos como respostas aos excessos de relativismo e inversão de valores presentes na sociedade contemporânea. Não há como uma Igreja consolidada, que tem o matrimônio como um sacramento, aceitar que as pessoas casem e descasem como bem entendem. Devemos reconhecer que há muitos abusos na sociedade. Há exceções, certamente, mas, para esses casos, a Igreja considera haver nulidade pelo Tribunal Eclesiástico. Não cabe, aqui, um julgamento, de certo ou errado, mas de entendermos um discurso, conservador para muitos, que é uma resposta ao contexto atual. Se a Igreja Católica mudasse os seus dogmas de acordo com novos contextos, certamente não teria sobrevivido por tanto tempo. E essa perspectiva é apresentada no final do parágrafo 29.

Vista a complexidade do contexto cultural em que vive a Igreja em muitos países, o Sínodo recomendou ainda que se tivesse o máximo cuidado pastoral com a formação dos nubentes e a verificação prévia das suas convicções sobre os compromissos irrenunciáveis para a validade do sacramento do Matrimônio. Um sério discernimento a tal respeito poderá evitar que impulsos emotivos ou razões superficiais induzam os dois jovens a assumir responsabilidades que depois não poderão honrar ${ }^{41}$. [...] Matrimônio e família são instituições cuja verdade deve ser promovida e defendida de qualquer equívoco, porque todo o dano a elas causado é realmente uma ferida que se inflige à convivência humana como tal.

40 Luiz Pondé: Filósofo, professor de Ciências da Religião na PUC/SP e de Filosofia na FAAP, em entrevista à Cláudia, com publicação em 19/11/2007. Disponível em:

http://claudia.abril.com.br/materia/polmicas-na-igreja-2397/?p=/comportamento/atualidades

${ }^{41}$ Ver Propositio 40 (Nota do autor). 


\subsection{A EUCARISTIA E A DEFESA DA VIDA HUMANA: COERÊNCIA EUCARÍSTICA}

Em meio a questões como matrimônio e, implicitamente, homossexualismo, uma questão merece destaque, pois se refere a alguns assuntos que têm feito parte das pautas de discussões políticas, religiosas e de saúde pública: o aborto e a eutanásia.

É importante salientar aquilo que os padres sinodais designaram por coerência eucarística, à qual está objetivamente chamada a nossa existência. Com efeito, o culto agradável a Deus nunca é um ato meramente privado, sem consequências nas nossas relações sociais: requer o testemunho público da própria fé. Evidentemente isto vale para todos os batizados, mas impõe-se com particular premência a quantos, pela posição social ou política que ocupam, devem tomar decisões sobre valores fundamentais como o respeito e a defesa da vida humana desde a concepção até a morte natural, a família fundada sobre o matrimônio entre um homem e uma mulher, a liberdade de educação dos filhos e a promoção do bem comum em todas as suas formas ${ }^{42}$. Estes são valores não negociáveis. Por isso, cientes da sua grave responsabilidade social, os políticos e os legisladores católicos devem sentir-se particularmente interpelados pela sua consciência retamente formada a apresentar e apoiar leis inspiradas nos valores impressos na natureza humana ${ }^{43}$. Tudo isto tem, aliás, uma ligação objetiva com a Eucaristia (1 Cor 11, 27-29). Os bispos são obrigados a recordar sem cessar tais valores; faz parte da sua responsabilidade pelo rebanho que lhes foi confiado ${ }^{44}$. $(S C n .83)$

Podemos perceber, em seu discurso, a presença implícita de um discurso que a Igreja veementemente recusa: o da legalização do aborto e da eutanásia. Essa é uma questão muito cara à religião, bem como à saúde pública, e pelo mesmo motivo: o respeito à vida. Bento XVI recusa um discurso que defende, em especial nos países pobres, a legalização do aborto como forma de se evitar sua clandestinidade. Há, ainda, um discurso difundido pela Igreja que é muito contestado: o de não aceitação dos meios de contracepção e o da condenação do aborto em qualquer situação. O uso de contraceptivos é comum na sociedade e o aborto, em alguns casos como estupro ou má formação, é aceito. Essa polêmica coloca a Igreja como desvinculada do seu tempo. O que Bento XVI afirma é que se trata de respeito à vida. Em outra oportunidade, Bento XVI já afirmara: o que iríamos dizer às gerações futuras se hoje defendêssemos leis que atentam contra a

42 Ver João Paulo II, Carta enc. Evangelium vitæ (25 de Março de 1995): AAS 87 (1995), 401522; Bento XVI, Discurso à Pontifícia Academia para a Vida (27 de Fevereiro de 2006):AAS 98 (2006), 264-265. (Nota do autor)

43 Ver Congr. para a Doutrina da Fé, Nota doutrinal sobre algumas questões relativas à participação e comportamento dos católicos na vida política (24 de Novembro de 2002): AAS95 (2004), 359-370. (Nota do autor)

44 Ver Propositio 46. (Nota do autor) 
vida humana? É este o legado da Igreja Católica, aqui, reafirmado pelo papa e pelos bispos sinodais. Tais discursos estão numa arena de conflitos na sociedade e bem longe de um consenso, se é que possa haver algum consenso nesse caso. Observemos algumas contrapalavras:

[...] O termo "inegociável”, aplicado a questões como o aborto, a eutanásia, o divórcio, as uniões homossexuais ou o ensino católico, resulta significativo. O cerrar fileiras vem junto com um certo retorno a valores pré conciliares, como a missa em latim e o canto gregoriano, preferíveis, segundo a Exortação, às missas em língua local e aos acompanhamentos musicais mais ou menos modernos. A lembrança de que os católicos divorciados e casados de novo não podem receber a comunhão, e que devem esforçar-se para compensar sua situação irregular com "penitências e obras de caridade", complementa um quadro ao mesmo tempo retrógrado e, em um sentido político, "revolucionário". (El País, Madrid,- 1403 -2007 artigo de Enric González, correspondente em Roma)45.

A Igreja Católica se arroga o direito de interferir em programas políticos dos governos, despojando deputados católicos do vínculo com seus eleitores e do compromisso com a democracia dos Estados laicos. Segundo o documento, os parlamentares católicos devem defender a família, o matrimônio, o ideário da Igreja, sem considerar outras denominações religiosas ou mesmo os cidadãos não-crentes. É como se esses parlamentares estivessem no Congresso somente a serviço da Igreja 46 .

Quando o papa cobra "coerência eucarística" de políticos católicos, entendemos isso como um discurso que se faz a partir de outros que circulam na sociedade. Para a Igreja, não é coerente o fiel professar uma fé que defende a vida, que condena o aborto e a eutanásia, e, no parlamento, votar a favor da legalização destes. O texto, ainda, faz referência à família: "pela posição social ou política que ocupam, devem tomar decisões sobre valores fundamentais como o respeito e defesa da vida humana desde a concepção até a morte natural, a família fundada sobre o matrimônio entre um homem e uma mulher”. Se ele faz um apelo por essa coerência, fica claro que um discurso de incoerência (na visão da Igreja) existe. Há uma voz não mostrada, mas que faz parte de tal discurso, uma voz que questiona, especialmente, a não aceitação do aborto em casos especiais, bem como da eutanásia; discursos, mesmo dentro da própria Igreja, que começam a se abrir ao entendimento da união homossexual. São discursos que fervilham na sociedade

\footnotetext{
${ }^{45}$ Orlando Fedeli - "Reações a Exortação Apostólica Sacramentum Caritatis do Papa Bento XVI" MONTFORT Associação Cultural Online, 14/12/2012 às 07:27h http://www.montfort.org.br/index.php?secao=veritas\&subsecao=igreja\&artigo=reacoes_sacra $\underline{\text { mentum\&lang }=\text { bra }}$

46 Regina Jurkewicz. Professora de teologia, pesquisadora e coordenadora-executiva da ONG Católicas pelo Direito de Decidir, em entrevista à Cláudia, com publicação em 19/11/2007. Disponível em: http://claudia.abril. com.br/materia/polmicas-na-igreja 2397/?p=/comportamento/atualidades
} 
atual e com os quais a Igreja convive diariamente e, por isso, estiveram em pauta no Sínodo.

Há muitas vozes sociais que falam nesse discurso do papa. Mais uma vez, o seu texto se caracteriza pela conclusibilidade, ou seja, por um discurso que se pretende acabado, mas que, ao mesmo tempo, provoca, em seu interlocutor, uma posição responsiva de concordância ou não. Isso se dá, especialmente, porque não se trata, aqui, de um discurso restrito ao universo católico/religioso, mas de forte cunho social. Assim, tal discurso vai além dos interlocutores previstos pela exortação. Trata-se, portanto, de um discurso social que tem, de acordo com Bakhtin, além do interlocutor previsto, um "superdestinatário".

[...] todo enunciado se dirige não somente a um destinatário imediato, cuja presença é percebida mais ou menos conscientemente, mas também a um superdestinatário, cuja compreensão responsiva, vista sempre como correta, é determinante da produção discursiva. A identidade desse superdestinatário varia de grupo social para grupo social, de uma época para outra, de um lugar para outro: ora ele é a Igreja, ora o partido, ora a ciência, ora a "correção política". Na medida em que toda réplica, mesmo de uma conversação cotidiana, dirige-se a um superdestinatário, os enunciados são sociais (FIORIN, 2008, p.27).

O que vemos é que o autor, ao longo do texto, em especial nesse parágrafo 83, nos coloca diante de alguns desses discursos sociais que emanam da ciência, da política, da mídia, ou mesmo da própria Igreja, e que devem ser rechaçados ou assumidos. Discursos sociais que se revelam nas opiniões individuais.

\subsection{O SENTIDO DO REPOUSO E DO TRABALHO}

Outro tema que nos chama a atenção é o trabalho. O parágrafo 74 nos recorda que "o trabalho é para o homem e não o homem para o trabalho". Uma sociedade capitalista, como esta na qual estamos inseridos, cria necessidades de consumo e de produção em detrimento da qualidade de vida do trabalhador. Por isso, é bastante oportuno este apelo feito, também, à sociedade civil:

É particularmente urgente no nosso tempo lembrar que o dia do Senhor é também o dia de repouso do trabalho. Desejamos vivamente que isto mesmo seja reconhecido também pela sociedade civil, de modo que se possa ficar livre das obrigações laborais sem ser penalizado por isso. De fato, os cristãos - não sem relação com o significado do sábado na tradição hebraica - viram no dia do Senhor também o dia de repouso da fadiga quotidiana. Isto possui um significado bem preciso, ou seja, constitui uma relativização do trabalho, que tem por finalidade o homem: o trabalho é para o homem e não o homem para o trabalho [...]. Como já tive ocasião de afirmar, "o trabalho reveste uma importância primária para a realização do homem e o progresso da sociedade; por isso torna-se necessário que aquele seja sempre organizado e realizado no pleno respeito da dignidade humana e ao serviço do bem comum. Ao mesmo tempo, é indispensável que o 
homem não se deixe escravizar pelo trabalho, que não o idolatre pretendendo achar nele o sentido último e definitivo da vida" ${ }^{47}$ [...]. (SC n.74)

Esse discurso rechaça claramente um outro vinculado à sociedade de consumo, que sacrifica o trabalhador em prol de mais produção e menos custo. Apoiando-se no Dia do Senhor, o papa expande o tema para o respeito ao descanso do trabalhador. Aproveitando a homilia proclamada na solenidade de São José, Bento XVI nos traz um discurso muito oportuno nos dias atuais: "é indispensável que o homem não se deixe escravizar pelo trabalho, que não o idolatre pretendendo achar nele o sentido último e definitivo da vida”. Tal discurso nos coloca diante de outros discursos consumistas que deixaram a sociedade na situação em que se encontra hoje: em crise, doente e obstinada pelo trabalho e pelo consumo. Que caminho tal discurso capitalista nos tem mostrado? É este o discurso a ser rechaçado por Bento XVI.

\section{CONSIDERAÇÕES FINAIS}

O término desta exortação não determina o fechamento do seu discurso. Cada gênero apresenta a sua forma de atividade responsiva. "Cada réplica [...] possui uma conclusibilidade específica ao exprimir certa posição do falante que suscita resposta, em relação à qual se pode assumir uma posição responsiva” (BAKHTIN, 2006a, p.275).

Por seu caráter polifônico, ou seja, de comportar outros discursos em seu discurso, este texto nos mostra a sua inserção num contexto que inclui previamente textos anteriores que lhe inspiraram ou influenciaram. Alguns desses discursos são mostrados por meio de citações; outros não são mencionados diretamente, mas se deixam transparecer. Esse vínculo com discursos aos quais ele responde, e com aqueles que lhe respondem, traz à tona muitos discursos acerca do objeto religioso, sejam eles de aceitação ou de recusa. Assim, a palavra se abre num diálogo infinito.

O enunciado existente, surgido de maneira significativa num determinado momento social e histórico, não pode deixar de tocar os milhares de fios ideológicos existentes, tecidos pela consciência ideológica em torno de um dado objeto de enunciação, não pode deixar de ser participante ativo do diálogo social. Ele também surge desse diálogo como seu prolongamento, como sua réplica, e não sabe de que lado ele se aproxima desse objeto. (BAKHTIN, 1988, p.86)

Diante dessa afirmação de Bakhtin, podemos inferir acerca do dialogismo nesta exortação que, embora aparente ser um texto doutrinador e pregador de

47 Homilia na solenidade de São José (19 de Março de 2006): AAS 98 (2006), 324. 
verdades, ele existe em função de outros discursos que o precederam e de outros que o sucederão, discursos que ele mesmo traz à luz de sua palavra. As suas palavras não fecham o discurso, apenas lançam novos desafios aos seus interlocutores. E o discurso se projeta exatamente por esse desafio externo que lhe é proposto. Como reflete Bakhtin:

Qualquer discurso da prosa extra-linguística - de costumes, retórica, da ciência - não pode deixar de se orientar para o "já-dito", para o "conhecido", para a "opinião pública" etc. A orientação dialógica é naturalmente um fenômeno próprio a todo discurso. Tratase da orientação natural de qualquer discurso vivo. Em todos os seus caminhos até o objeto, em todas as direções, o discurso se encontra com o discurso de outrem e não pode deixar de participar, com ele, de uma interação viva e tensa (BAKHTIN, 1988, p.88).

Tais desafios implicam mudanças nas relações. Sabemos que o discurso religioso católico trabalha pela manutenção de uma verdade. O que acontece é que diante das mudanças nas relações sociais, tal discurso não se modifica, mas se ressignifica na sua doutrina, inserindo-a em cada novo contexto. Nisso trabalha com uma memória de futuro, pois se projeta na construção do novo (mesmo que esse novo seja uma atualização do antigo). Produz discursos que reavaliam e "deslocam palavras de um determinado contexto para outro. [...] Uma nova significação se descobre na antiga e através da antiga, mas a fim de entrar em contradição com ela e de reconstruí-la” (Miotello, 2006, p.284). É um discurso consolidado, mas ciente de sua instabilidade. Por isso busca novos contextos de ressignificação e, ao mesmo tempo, de reafirmação de sua ideologia. Assim, o discurso da exortação conflui "entre a Memória do Passado, os sentidos dados, e a Memória do Futuro, onde os sentidos ainda apontam para realidades a serem construídas” (idem, p.285). Nessa confluência está o seu Projeto de Dizer, a sua expectativa para construir um futuro um pouco melhor que o que mostram os erros do passado e, também, os do presente.

Nessa linha, queremos, ainda, situar o discurso religioso na relação indicada por Miotello (2005) entre discursos fundadores e discursos formadores.

A Igreja Católica é uma instituição cujas relações de dominação hegemônica são confrontadas constantemente. A sua estrutura comporta um

discurso fundador, que se apresenta sempre como um discurso explicador, nunca exaurido, e que vem pelas informações trazidas do passado, transportadas pelo baú da história e das interações havidas, e recriadas como possibilidade a todo instante; por outro lado, há em perspectiva de jogo social e interativo um discurso formador, que toma como parâmetro o futuro, o por-vir, os projetos de ser (MIOTELLO, 2005, p.271). 
Entendemos, pois, que o discurso produzido por Bento XVI (e pelos bispos sinodais) está nessa arena de conflitos de tais discursos: um olhar para o futuro da Igreja, mas alicerçado na memória do passado. Que caminhos o papa nos apresenta? Existe, verdadeiramente, um olhar para o futuro da Igreja ou, apenas uma recordação do passado?

Sugerimos essa situação por entendermos a Igreja Católica como construtora de poder hegemônico. Esse princípio de hegemonia começa no próprio conceito de unificação da Igreja Católica - é uma instituição que se pretende coesa, mas coesa em relação ao discurso oficial do Vaticano. Assim, trata-se de um discurso que se pretende único e monológico, que visa garantir um eco permanente, universal e necessário. Mas como a hegemonia sempre é apenas um dos lados das relações, há outros discursos, inclusive na própria Igreja,

que se apresentam como contrapalavras ativas e responsivas, e garantem a obrigação da mudança pelo embate social e instauram a possibilidade da quebra e de troca do instituído. Discurso hegemônico não vem com garantia de eternidade, pois que é constituído na luta social, e na luta perde e ganha contornos sempre renovados (MiOTELLO, 2005, p.275).

A análise desse discurso abre uma perspectiva de se pensar no discurso religioso católico oficial como um discurso que se pretende hegemônico e, por isso, enfrenta muitas contrapalavras; mas também, apresenta tal discurso como sendo ele próprio uma contrapalavra aos discursos dominantes na sociedade. É ele, ao mesmo tempo, o que se pretende hegemônico, com pretensões de ser único, e um discurso que desafia o discurso construído na sociedade capitalista e difundido pelas mídias. Se, por um lado, é doutrinador; por outro, mostra-se transformador na medida em que preza e prega valores que a sociedade consumista e excludente há muito perdeu. $\mathrm{O}$ fato de tal discurso se manter indissolúvel, mesmo em meio aos desafios dos diferentes contextos históricos, é também uma contrapalavra. A sua resposta mediante as mudanças de paradigmas sociais é a manutenção dos seus dogmas. Podemos observar que o discurso de Bento XVI não traz novidades (e, talvez, não seja essa a sua intenção), firmando-se, assim, como de resgate da tradição.

Entendemos perfeitamente que essa questão não se esgota nisso. Há de se considerar que a sociedade criou um discurso que não é diretamente um desafio aos dogmas da Igreja; foi construído nas relações capitalistas que se estabeleceram no século XX. 
O assunto não se esgota nisso, portanto. Pensemos que o projeto de dizer do discurso analisado se constitui no limite que, por um lado, está "na relação dialógica do enunciado com os enunciados que o antecederam no campo da comunicação em que se realiza e, por outro, na relação igualmente característica com os enunciados ou ações responsivas que o sucedem" (MiOTELLO\&TURATI, 2011, p. 288).

Há, por conseguinte, questões que este estudo fez surtir. Mais que respostas, há perguntas ${ }^{48}$.

\section{REFERÊNCIAS}

BAKHTIN, Mikhail. Questões de literatura e de estética. São Paulo: Hucitec, 1988.

Estética da Criação Verbal. São Paulo: Martins Fontes, 2006a.

. Marxismo e filosofia da linguagem. 12. ed. Trad. Michel Lhud e Yara F. Vieira. São Paulo: Hucitec, 2006b.

BENTO XVI. Caritas in veritate. São Paulo: Paulinas, 2009.

Sacramentum Caritatis. São Paulo: Paulinas, 2007.

BRANCO, Nanci Moreira. O dialogismo e a construção de sentido nas cartas encíclicas do papa Bento XVI. Dissertação de mestrado defendida em 2012 e disponível em: http://www.bdtd.ufscar.br/htdocs/tede Simplificado/tde_arquivos/19/TDE-2012-1116T111313Z-4795/Publico/4677.pdf.

CATECISMO DA IGREJA CATÓLICA, [CIC]. 2, ed. Editora: Vozes, Paulinas, AveMaria, 1993.

CONCÍLIO VATICANO II. "Lumen gentium". In: Compêndio do Vaticano II: constituições, decretos, declarações. Petrópolis: Vozes, 2000.

. "Sacrosanctum Concilium". In: Compêndio do Vaticano II: constituições, decretos, declarações. Petrópolis: Vozes, 2000.

CRUZ, Washington. Sínodo Arquidiocesano: o amor de Cristo nos uniu. Goiânia: Arquidiocese de Goiânia, 2008. (Série Cartas Pastorais)

DENZINGER, Heinrich; HÜNERMANN, Petrus. Enchiridion symbolorum, definitionum et declarationum de rebus fidei et morum. Tradução de José Marino e Johan Konings. São Paulo: Paulinas: Loyola, 2007. (bilíngüe)

FARACO, Carlos Alberto. Linguagem e diálogo - as ideias linguísticas do círculo de Bakhtin. São Paulo: Parábola, 2009.

FIORIN, José Luiz. Introdução ao pensamento de Bakhtin. São Paulo: editora Ática, 2008.

48 Essas considerações, assim como a análise, têm como base o estudo acerca das encíclicas de Bento XVI, em Branco, 2012. 
FOUCAULT, Michel. A ordem do discurso. 16. ed. Trad. Laura Fraga de Almeida Sampaio. São Paulo: Edições Loyola, 2008.

GEGe. Palavras e contrapalavras - Caderno de estudos I - Glossariando conceitos, categorias e noções de Bakhtin. São Carlos: Pedro \& João Editores, 2009.

GEGe. Palavras e contrapalavras - Caderno de estudos II - Conversando sobre os trabalhos de Bakhtin. São Carlos: Pedro \& João Editores, 2010.

GONZÁLEZ, Justo L. Uma história do pensamento cristão. Vol. I. Braga: Ed. Cultura Cristã, 2004.

JAPIASSÚ, Hilton e MARCONDES, Danilo. Dicionário básico de Filosofia. Rio de Janeiro: Jorge Zahar Ed., 2008.

LORENZO, Juan Luis Martínez. "Sacramentum Caritatis: Reseña”. In. Ecclesia Digital. España. Disponível em http://www.revistaecclesia.com/?option=com_content\&task=view \&id=10507 \&Itemid=49 Acessado em 16 de agosto de 2012.

MIOTELLO, V. A questão da relação dos discursos fundadores com os discursos formadores. In Triboluminescểncia. GEGe (org). São Carlos: GEGe, 2005. Páginas: 271-281

. A memória do passado em jogo com a memória do futuro constitui sentidos agora. Daí que os projetos de dizer dos sujeitos têm importância. In Veredas

Bakhtinianas .GEGe (org). São Carlos: GEGe, 2006. Páginas: 277-286

Ideologia in Bakhtin conceitos-chave. Beth Brait (org.) São Paulo: Editora Contexto, 2008. Páginas: 167-176

MIOTELLO, V. \& TURATI, C. Para uma leitura do texto materialmente heterogêneo. In Análise do discurso: Teorizações e Métodos. Baronas e Miotello (org). São Carlos: Pedro \& João Editores, 2011. Páginas: 285-302

PADEN, William E. Interpretando o sagrado: modos de conceber a religião. São Paulo: Paulinas, 2001. 